\title{
Ultrastructural Morphological Alterations during Hyperoxia Exposure in Relation to Glutathione Peroxidase Activity and Free Radicals Productions in the Mitochondria of the Cortical Brain
}

\author{
Alteraciones Morfológicas Ultraestructurales durante la Exposición a la Hiperoxia \\ en Relación con la Actividad de la Glutatión Peroxidasa y la Producción de \\ Radicales Libres en las Mitocondrias de la Corteza Cerebral
}

Ismaeel Bin-Jaliah ${ }^{1}$ \& Al-Said Haffor ${ }^{2}$

BIN-JALIAH, I. \& HAFFOR, A. S. Ultrastructural morphological alterations during hyperoxia exposure in relation to glutathione peroxidase activity and free radicals productions in the mitochondria of the cortical brain. Int. J. Morphol., 36(4):13101315,2018

SUMMARY: Exposure to normobaric hyperoxia $(\mathrm{NH})$ is known to increase the production of reactive oxygen species (ROS) by mitochondria. The present study was designed to examine mitochondrial ultrastructure morphological changes in the cortical brainin relation to glutathione peroxidase (GPX) activity and free radicals (FR) productions in brain tissue during hyperoxia exposure. The experimental groups were exposed to $\mathrm{NH}$ for 24 and $48 \mathrm{~h}$ continuously. Following the exposure periods, animals were sacrificed and cortical tissues were divided randomly into two parts; the first part was processed for the ultrastructural examination and the second was homogenized for GPX and FR determinations. Analysis of variance (ANOVA) showed that the main effects of O2 exposure periods were significant $(\mathrm{p}<0.05)$ for GPX and FR. Pair-wise means comparisons showed that NH elevated the average (+SE) GPX activity significantly $(\mathrm{p}<0.05)$ from the baseline control value of $5670.99+556.34$ to13748.42+283.04 and $15134.19+1529.26$ U/L with increasing length of $\mathrm{NH}$ exposure period from 24 to $48 \mathrm{~h}$, respectively. Similarly, FR production was increased significantly $(\mathrm{p}<0.05)$ to $169.73+10.31$ and $185.33+21.87$, above baseline control of $105.27+5.25$ Unit. Ultrastructure examination showed that $\mathrm{O} 2$ breathing for $48 \mathrm{~h}$ resulted in giant and swelled mitochondria associated with diluted inner membrane and damaged cristae. These mitochondria pathological alterations were associated with damages of myelin, axonal and cellular organelles. Normobaric-hyperoxia inducts mitochondria oxidative stress (MOS) and the subsequent rise of ROS causes variety of ultrastructure morphological pathological alterations in the organelles of cortical brain cells.

KEY WORDS: Cortical Brain; Morphological pathological alterations; Normobaric hyperoxia; Reactive oxygen species; Reactive nitrogen species; Ultrastructure.

\section{INTRODUCTION}

The brain is the center of the nervous system and is the most complex organ in the body. The normal morphology of the brain is the base for its function to exert centralized control over the other organs of the body. This centralized control allows coordinated responses to changes in the environment via neural and hormonal actions. The therapeutic use of $\mathrm{O}_{2}$ breathing at room pressure (normobaric hyperoxia - NH) is useful during critical therapeutic conditions; however, its use at high concentration and longer duration induct oxidative stress. Mitochondrial oxidative stress (MOS) occurs when the redox balance is lost. Oxygen breathing is relevant in the pathogenesis of the small oxidant byproducts, such as superoxide radical $\left({ }^{*} \mathrm{O}_{2}-\right)$, hydroxyl radical $(* \mathrm{OH})$ nitric oxide radicals $(* \mathrm{NO})$. Those small byproducts are constantly produced as a consequence of normal cellular metabolism but if their production exceeds their removal rate the accumulation of reactive oxygen species (ROS) occurs. The accumulations of ROS induct cellular damages and the subsequent cellular and tissue morphological abnormality.

The role of glutathione in the detoxification (GPX) of ROS had been well established (Elayan et al., 2000; Gaber et. al., 2001; Bin-Jaliah et al., 2009). Reduced glutathione (GSH) is oxidized in the presence of glutathione peroxidase (GSH-Px) and hydrogen peroxide $\left(\mathrm{H}_{2} \mathrm{O}_{2}\right)$ or lipid

\footnotetext{
${ }^{1}$ Department of Physiology, College of Medicine, King Khalid University, Abha, Saudi Arabia.

${ }^{2}$ Department of Basic Medical Sciences, College of Medicine, Dar Al-Uloom University, Riyadh, Saudi Arabia.
} 
hydroperoxides resulting in the formation of nontoxic compounds. Therefore the use of increasing periods of $\mathrm{O}_{2}$ breathing can be a useful model for studying the wideranging effects of oxidative stress on neurological morphological alterations and its related function, which complements more traditional in vitro models of oxidative stress used at normobaric pressure (Pellmar, 1995). The utility of employing hyperoxia as an oxidative stimulus is that the natural substrate, molecular $\mathrm{O}_{2}$, is supplied to the cell, which, in turn, reacts in one or more biochemical pathways to produce various free radicals (Balentine, 1982).

In view of the brief introduction summarized above, the current study aimed to characterize the ultrastructure morphological changes in the mitochondria of cortical neurons and the related GPX activity and FR accumulations inducted by oxygen breathing.

\section{MATERIAL AND METHOD}

Study Design and Samples Preparation. Experiments were performed with the approval of the Biomedical Research Ethics Committee at the College of Medicine, King Khalid University, Abha, Saudi Arabia, and all procedures were performed according to the Guide for the Care and Use of Laboratory Animals published by the US National Institutes of Health (NIH publication No. 85-23, revised 1996). Forty five adult Wister albino male rats, Rattus norvigicus, matched for age and body weight, were randomly assigned to 3 groups; 15 animals each. The first group served as control (C) and the $2^{\text {nd }}$ and $3^{\text {rd }}$ groups were exposed to hyperoxia for $24 \mathrm{~h}$ (HP-24) and $48 \mathrm{~h}$ (HP-48), respectively. Following the exposure periods, animals were humanely sacrificed by cervical dislocation, and cortical tissues were collected and divided randomly into two parts; the first processed for the ultrastructural examination and the second was homogenized for GPX and FR determinations.

Hyperoxia Exposure. Animals were placed in a closed box that has an inlet and outlet. The inlet was connected to 100 $\% \mathrm{O}_{2}$ medical grade tank in which the flow was maintained at $5 \mathrm{~L}$ per $\min (\mathrm{LPM})$. The regulator of the tank was provided with a humidifier in order to saturate the inspired air with $\mathrm{H}_{2} \mathrm{O}$. The outlet of the box was connected to vacuum line that was adjusted at 3 LPM to ensure that the concentration of oxygen in the box would be approximately equal to the concentration in the tank (Haffor, 2004; Bin-Jaliah et al.).

Ultrastructure Examination Procedures. Brain tissue samples were fixed by immersion in $3 \%$ buffered cold ( 4 ${ }^{\circ} \mathrm{C}$ ) of glutaraldhyde then post fixed in $1 \%$ osmium tetroxide.
Fixed tissue were dehydrated in graded concentrations of ethyl alchol $(30 \%, 50 \%, 70 \%, 90 \%)$ for $30 \mathrm{~min}$ and finally in absolute ethanol (100\%) for $40 \mathrm{~min}$. Dehydrated tissue samples were then placed in propylene oxide to get rid of ethanol and render the tissues to become penetrateable for the embedding media. This step was done at room temperature for $60 \mathrm{~min}$. Tissue samples were infiltrated by transferring them from propylene oxide to a mixture of expoxy resins. First, samples were placed in a mixture of propylene oxide and resins at the ratio of $1: 1$ for $2 \mathrm{~h}$ and lastly placed in pure epoxy mixture overnight. Tissue samples were embedded in the epoxy mixture using polyethylene been capsules. Polymerization of the resin was done at 60 ${ }^{\circ} \mathrm{C}$ for $48 \mathrm{~h}$. Ultra sections $(70 \mathrm{~nm})$ were made and double stained with uranyl acetate and lead citrate. Ultra sections were mounted on carbon-coated grids, then examined and photographed by transmission electron microscope (JEOL $100 \mathrm{CX}$; JOEL, Tokyo, Japan) set at $80 \mathrm{kV}$ (Bin-Jaliah et al.; Haffor \& Alttas, 2010).

Free Radicals and Glutathione Peroxidase (GPX) Determinations. Brain tissue sample of a given rat was placed in $0.9 \%$ saline solutions ( $4: 1 \mathrm{ml}$ per $\mathrm{mg}$ wet tissue) and homogenized, using homogenizer (Ultra-Turrax System, IKA Werke, Germany) with the sample tube held on ice. The homogenates were then centrifuged for $10 \mathrm{~min}$ at 3000 rpm (Zentrifugen 2405 system, Lahr, Germany). The resultant supernatant fraction from each brain homogenate was then recovered and used for free radicals, and glutathione peroxidase activity, determinations. Free radicals production was measured, using the d-ROMs-2 test kits (Health \& Diagnostic, Italy) according to the manufacturer's instructions. The test measures the levels of hydroperoxides (R-OOH) which are generated by peroxidation of biological compounds; lipid, amino acids, nucleic acids. This test is based on the principle of the ability of hydrogen peroxides to generate free radicals after reacting with some transitional metals $\left(\mathrm{Fe}^{2+} / \mathrm{Fe}^{3+}\right)$, according to Fenton's Reaction as follows: $\mathrm{H}_{2} \mathrm{O}_{2}+\mathrm{Fe}^{2+}=* \mathrm{OH}+\mathrm{OH}-+\mathrm{Fe}^{3+}$. Thus, the hydrogen peroxides of biological sample generate free radicals (alcoxy and peroxyl radicals) after exposure to a transitional metal $\left(\mathrm{Fe}^{2+} / \mathrm{Fe}^{3+}\right)$. When a correctly buffered chromogen substance (N, N-diethyl-phenylendiamine) lead to the reduction of hydrogen peroxides which in turns colored as radical cation. Color intensity was read using spectrophotometer with peak absorbance of $505 \mathrm{~nm}$. In the d-ROMs test results were expressed in CARR units (CARR-U). One CARR U relates to $0.08 \mathrm{mg} \mathrm{H} 2 \mathrm{O} 2 / 100 \mathrm{ml}$. GPX was determined using Randox protocol (Randox, UK). The principle of this method is based on the specificity of GPx to catalyze the detoxification of hydrogen peroxide according to the following reaction: $2 \mathrm{GSH}+\mathrm{H}_{2} \mathrm{O}_{2}$ GPx GSSG $+2 \mathrm{H}_{2} \mathrm{O}$ (Bin-Jaliah et al.; Haffor \& Alttas). 
Statistical Analysis. Mean group differences for the dependent variable; GPX were evaluated using univariant ANOVA to reveal the main effect of each group on the dependent variables. Tukey-Kramer multiple comparisons were used to compare differences between each means pairs. All statistical analysis was conducted using SPSS program.

\section{RESULTS}

PART-I: Descriptive Findings. Hyperoxia elevated the average $( \pm \mathrm{SE})$ GPx activity in the brain tissue from the baseline control value $5670.99+556.34$ to $13748.42+283.04$ and $15134.19+1529.26 \mathrm{U} / \mathrm{L}$ with increasing length of $\mathrm{O}_{2}$ exposure period from 24 to $48 \mathrm{~h}$. The corresponding changes in free radicals were following 24 and $48 \mathrm{~h}$ were $169.73+10.31$ and 185.33+21.87 Carr, respectively (Table I).

PART-II: Inferential Findings. The results of univariant ANOVA (Table II) showed that the main effects of hyperoxia on both GPX and FR were significant $(\mathrm{p}<0.05)$. That means that the difference between the overall mean for GPX and FR of all potential observations and the individual mean for each hyperoxia group was significant $(\mathrm{p}<0.05)$ (Table II).
The results of multiple comparisons showed that GPX activity increased significantly ( $\mathrm{p}<.05)$, from baseline control values following 24 and $48 \mathrm{~h}$ of hyperoxi, respectively. Although GPX activity and FR accumulations continued to rise after $48 \mathrm{~h}$ but mean differences were not significant ( $p>0.05$ ), as compared to $24 \mathrm{~h}$ mean values (Table III). These results demonstrated the ability of brain tissues to use endogenous antioxidants, more specific to GPX protein to offset the oxidative stress state up to their antioxidants potential, when $48 \mathrm{~h}$ of $\mathrm{O}_{2}$ exposure had been lapsed.

\section{PART-III: Ultrastructure Findings.}

Mitochondria and Myelin Alterations. Mitochondrial abnormalities were observed in both cellular body and neuropil in the different regions of both hemisphere of the cerebral cortex. Gross examination (Figs. 1A,B) revealed that increased vacuolated, swollen and giant mitochondria in cerebral cortex of the $\mathrm{NH}$ group, exposed group to $\mathrm{O}_{2}$ breathing. There were no observed differences when mitochondrial abnormalities in cellular body were compared with those mitochondria in neuropil. Preserved mitochondria were frequently found in close proximity with well-preserved

Table I. Glutathione Peroxidase (GPX) Activity (U/L) and Free Radicals (FR) in the Brain.

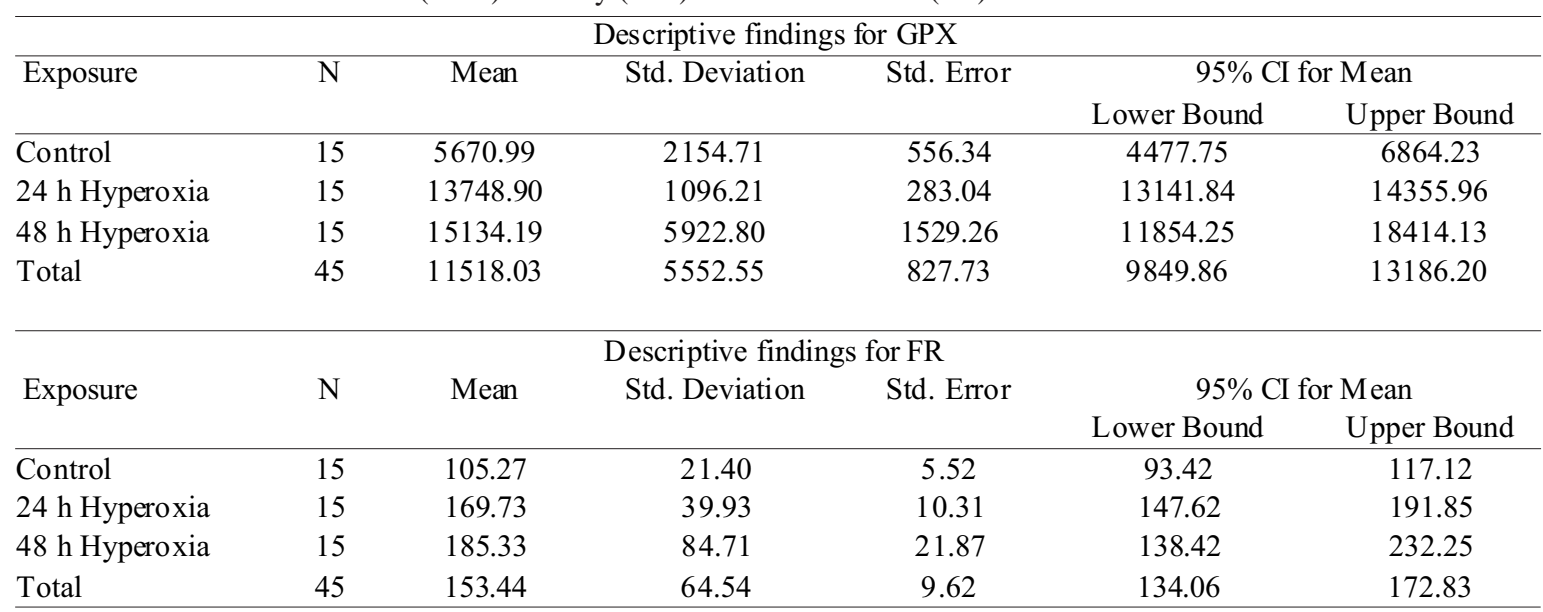

Table II. One Way Analysis of Variance (ANOVA) for GPX and FR.

\begin{tabular}{lccccc}
\hline \multicolumn{7}{c}{ Glutathione Peroxidase (GPX) } & & \\
& Sum of Squares & df & Mean Square & F & Sig. \\
\hline Between Groups & 783619736.90 & 2 & 391809868.45 & $28.72^{*}$ & .000 \\
Within Groups & 572935998.48 & 42 & 13641333.30 & & \\
Total & 1356555735.38 & 44 & & & \\
& & & & & \\
Eree Radicals (FR) & Sum of Squares & df & Mean Square & F & Sig. \\
\hline Between Groups & 54049.911 & 2 & 27024.956 & $8.79 *$ & .001 \\
Within Groups & 129201.200 & 42 & 3076.219 & & \\
Total & 183251.111 & 44 & & & \\
\hline *p $<0.05$ & & & & &
\end{tabular}


BIN-JALIAH, I. \& HAFFOR, A. S. Ultrastructural morphological alterations during hyperoxia exposure in relation to glutathione peroxidase activity and free radicals productions in the mitochondria of the cortical brain. Int. J. Morphol., 36(4):1310-1315, 2018.

Table III. Tukey HSD Multiple Comparisons among Means.

\begin{tabular}{|c|c|c|c|c|c|c|}
\hline \multirow{3}{*}{ (I) Group } & \multicolumn{6}{|c|}{ Glutathione Perioxidase (GPX) } \\
\hline & \multirow[t]{2}{*}{ (J) Group } & \multirow[t]{2}{*}{ Mean Difference (I-J) } & \multirow[t]{2}{*}{ Std. Error } & \multirow[t]{2}{*}{ Sig. } & \multicolumn{2}{|c|}{$95 \%$ Confidence Interval } \\
\hline & & & & & Lower Bound & Upper Bound \\
\hline \multirow[t]{2}{*}{ Control } & 24 h HP & $-8077.91^{*}$ & 1348.65 & .000 & -11354.44 & -4801.39 \\
\hline & 48 h HP & $-9463.20^{*}$ & 1348.65 & .000 & -12739.73 & -6186.68 \\
\hline \multirow[t]{2}{*}{$24 \mathrm{~h} \mathrm{HP}$} & Control & $8077.91^{*}$ & 1348.65 & .000 & 4801.39 & 11354.44 \\
\hline & 48 h HP & -1385.29 & 1348.65 & .564 & -4661.81 & 1891.25 \\
\hline \multirow[t]{2}{*}{$48 \mathrm{~h} \mathrm{HP}$} & Control & $9463.20^{*}$ & 1348.65 & .000 & 6186.68 & 12739.73 \\
\hline & 24 h HP & 1385.29 & 1348.65 & .564 & -1891.24 & 4661.81 \\
\hline \multicolumn{7}{|c|}{ Free Radicals Accumulations (FR) } \\
\hline \multirow[t]{2}{*}{ (I) Group } & \multirow[t]{2}{*}{ (J) Group } & \multirow[t]{2}{*}{ Mean Difference (I-J) } & \multirow[t]{2}{*}{ Std. Error } & \multirow[t]{2}{*}{ Sig. } & \multicolumn{2}{|c|}{$95 \%$ Confidence Interval } \\
\hline & & & & & Lower Bound & Upper Bound \\
\hline \multirow[t]{2}{*}{ Control } & $24 \mathrm{~h} \mathrm{HP}$ & $-64.47^{*}$ & 20.25 & .008 & -113.67 & -15.26 \\
\hline & 48 h HP & $-80.07^{*}$ & 20.25 & .001 & -129.27 & -30.86 \\
\hline \multirow{2}{*}{$24 \mathrm{~h} \mathrm{HP}$} & Control & $64.47^{*}$ & 20.25 & .008 & 15.26 & 113.67 \\
\hline & 48 h HP & -15.60 & 20.25 & .723 & -64.80 & 33.60 \\
\hline \multirow[t]{2}{*}{48 h HP } & Control & $80.07^{*}$ & 20.25 & .001 & 30.86 & 129.27 \\
\hline & 24 h HP & 15.60 & 20.25 & .723 & -33.60 & 64.80 \\
\hline
\end{tabular}

. The mean difference is significant at the 0.05 level.

myelin sheet (Fig. 1A). In addition, degenerated and swollen mitochondria in the cellular body were close to the degenerated mitochondria that were observed in the neutropil (Fig. 1B). At higher magnification (Figs. 1C,D) of randomly selected axons of the cerebral cortex from both control and hyperoxia
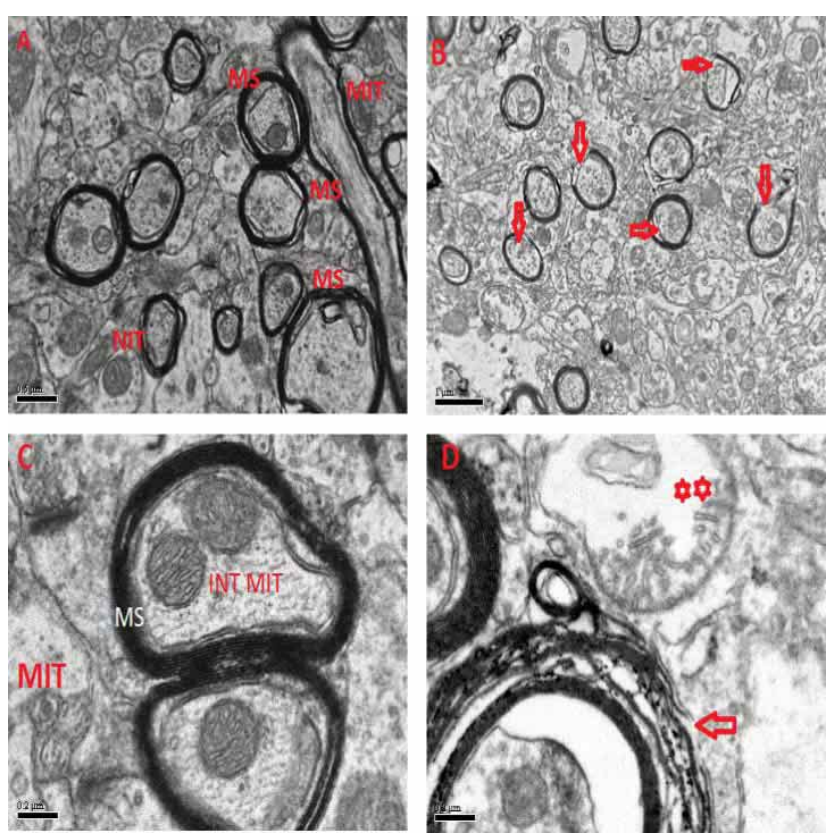

Fig. 1. A) Gross structure ( $\mathrm{x}=4500)$ showing normal mitochondria (MIT) was related to normal myelin sheet (MS). B) Gross structure $(\mathrm{x}=24300)$ showing loss of myelin sheet was related to mitochondria damage's. C) normal internal (INT MIT) and external mitochondria (MIT) with well-preserved myelin sheet (MS; $0.2 \mathrm{~m} \mathrm{x}=81000)$. D) Vacuolated and swollen mitochondria (**) in neuronal body and degeneration to myelin; $\mathrm{x}=101000$. groups micrograph clearly showed normal internal and external mitochondria with well-preserved myelin sheet (MS) that was associated with the presence of preserving structural arrangement and well-preserved myelin sheets that represented uniform ring around the axon (Fig. 1C). On the contrary, vacuolated (VM) and swollen mitochondria were coupled with myelin disarrangements which were characterized with diffused local disarrangement patterns (Fig. 1D).

Mitochondria and Axonal Knob Alterations. The micrograph from the cerebral cortex of control group (Fig. 2A) shows normal mitochondrial morphology that associated with well-preserved myelin on the axonal knob at synapse. On the contrary, the micrograph of Figure 3B from hyperoxia group showed abnormality swollen axonal knob that was associated with mitochondria degenerations; swollen mitochondria with deterioration of cristae, site of respiratory chain enzymes. Obviously all these morphological changes present a state of loco metabolic stress, oxidative stress.

Mitochondria, Nuclear and Pyramidal Cell Alterations. Figure $3 \mathrm{~A}$ of the control group showed morphological integrity of the nuclear contents could be predicted from the distribution of heterochromatin (HC) which plays a major role in genes expression. Clearly shown from the micrograph in Figure 3A. HC was uniformly scattered around the nucleus that was associated with normal mitochondria morphology inside and outside the cell. On the contrary, Figure 3B from hyperoxia exposed group, showed vacuolization of pyramidal cells with constricted and intended nucleus that was associated with mitochondrial hyperplasia and accumulation of fat droplet scattered around indicating an early signs of cellular apoptosis. 

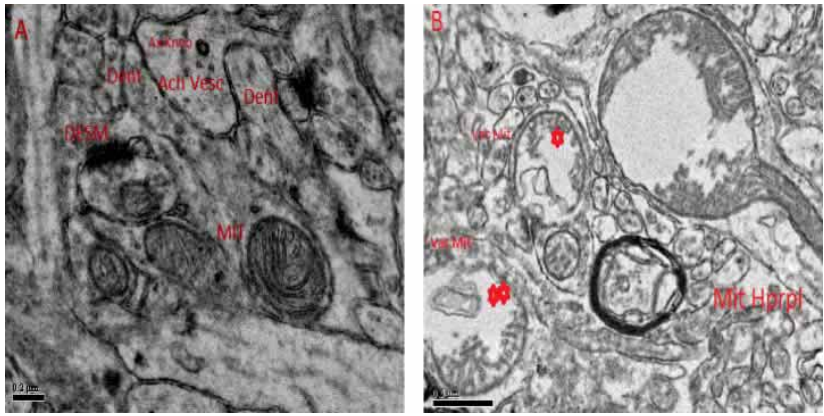

Fig. 2. A) normal mitochondria and desmosomes (DSM) $\mathrm{x}=81000$. B) Mitochondrial degeneration (*); vacuolated and swelled mitochondria in neuropil $(* *)$; and mitochondria hyperplasia (Mit Hprpl) $\mathrm{x}=60700$.

\section{DISCUSSION}

Firstly, the findings of the present study showed that lengthening of the period of exposure to $100 \%$ oxygen ( $\mathrm{PiO} 2$ $=706 \mathrm{mmHg}$ ) breathing to $48 \mathrm{~h}$ resulted in sustained rise of 2 folds for GPX activity and 1.5 folds for FR production in the brain tissue. $\mathrm{O}_{2}$ toxicity of the mitochondria in CNS (mCNS) is one of the best known examples of how acute exposure to an oxidative environment can disrupt the morphology of the neural cell and the subsequent malfunction (Balentine). Normally, when animals and humans breathe normobaric air, neural $\mathrm{PtiO}_{2}$ is surprisingly low, ranging from 1-3 Torr up to 30-34 Torr, in the cortical area of the brain (Piantadosi \& Tatro, 1990; Pellmar et al., 1994; Pellmar). Taking into consideration the level of $\mathrm{FIO}_{2}$ and the duration of exposure for $48 \mathrm{~h}$, utilized in the present study, one can predict that the neurological impairment, secondary to hyperoxia would be substantial. Furthermore, oxidation-reduction (redox) reactions are involved in normal signal transduction mechanisms such as $\mathrm{O}_{2}$ sensing (Lahiri et al., 1987; Lipton et al., 2001) and modulation of neuronal electrical activity (Clemens et al., 2001; Mulkey et al., 2003). Oxidative mitochondrial stress (OMS) in the CNS occurs when $\mathrm{O}_{2}$ tension is increased because of the subsequent rise in brain tissue $\mathrm{PO}_{2}\left(\mathrm{PtiO}_{2}\right)$ leading to a large proton gradient that induct variety of mitochondrial pathological alterations such as swelling, concentrated cristae, dilution of the inner and outer membrane (Haffor; Bin-Jaliah et al.). The possible exogenous mechanisms for continuous hyperoxia-induced reactive species reflect an additive effect of mitochondria oxidative stress - MOS (Crapo et al., 1980; Haffor; Haffor \& Alttas). Under oxidative stress mitochondria releases free radicals by-products such as hydrogen peroxide to the cytosol at higher rate than its elimination rate by cellular antioxidants (Sawyer \& Colucci, 2000). Thereafter, the accumulated protons ( $\mathrm{H}+$ ) leak from the inter-mitochondria membrane region to the matrix.
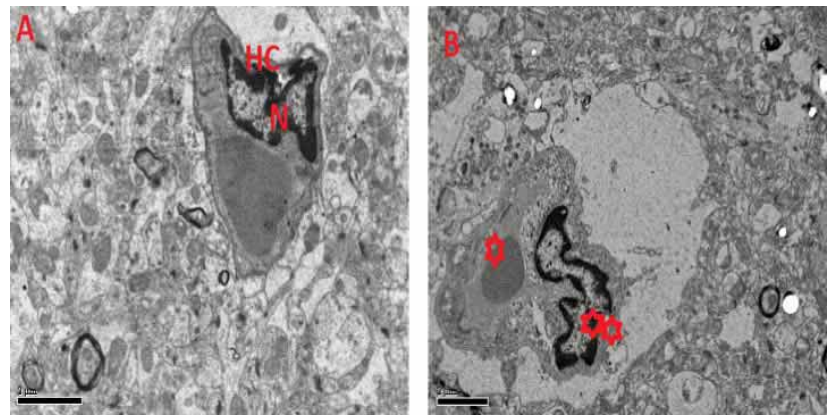

Fig. 3. A) Normal nucleus (N) with heterochromatin (HC) evenly scattered around the nucleus of cerebral pyramidal cell. B) Vacuolization of pyramidal cells in hyperoxia (*) with intended and constricted nucleus $(* *)$; bright white spots are fats droplets.

Several studies reported that exposure to hyperoxia for $24 \mathrm{~h}$ resulted in morphologic changes in the inner mitochondrial membrane (Elayan et al.; Bin-Jaliah et al.) that were similar to brain inflammation (Fridovich, 1998; Jankov et al., 2003). During longer duration of hyperoxia exposure such as $48 \mathrm{~h}$ the brain's antioxidant defenses are overwhelmed by the buildup of ROS in the mitochondria, nucleus, cytosol, membranes, and extracellular fluid compartments. Besides hyperoxia-induced-MOS exogenously, brain tissue produces nitro oxide, glutamate and related excitatory amino acids and that induct an excess shift in nitrasive-redox balance and the subsequent high turnover rate in cellular morphological alterations, cellular apoptosis, death and brain tissue damage (Hare et al., 1998; Demchenko et al., 2003). Clearly those observations emphasize the rise of ROS, in neurodegenerative disorders, such as Alzheimer's disease, Parkinson's disease and Duchenne muscular dystrophy.

Secondly, the ultrastructure findings of the present study showed that hyperoxia caused distal degeneration of axon with potential backward progression, from the knob toward the cell body. Clearly this directional degeneration is major pathological feature that explain sensory weakness and loss, mainly due to slow or absence axoplasmic signal flow. The distal axon myelin degeneration observed in the present study was associated with mitochondria damages, implying that the inability of the neuronal body to keep up with the metabolic demands of the axon. These findings may explain why most of psychiatric diseases begin in the most distal parts of nerves and large axons that have the highest metabolic and nutritional demands.

Thirdly, findings of the present study showed degenerated pyramidal neuron with swollen mitochondria in the astrocytes in the pyramidal layer of the cerebral cortex. These findings were consistent with previously reported (Slomka et al., 2008) who demonstrated that oxidative stress inducted by hyperthermia-induced was mainly manifested by damage in the pyramidal neurons up-to nearly $60 \%$ loss. 
Based on the results of the present study it could be concluded that normobaric-hyperoxia exposure induct mitochondria oxidative stress (MOS) and the subsequent rise of ROS causes variety of ultrastructure pathological alterations in the cortical brain cells. Endogenous antioxidants are delimited during continuous normobaric $\mathrm{O}_{2}$ breathing as ROS accumulation exceeds its elimination rate.

\section{ACKNOWLEDGEMENTS}

This research project was based on the mutual research interests of the authors who self-funded the project. The authors would like to express their gratitude to King Khalid University, Abha, Saudi Arabia for providing administrative and technical support.

BIN-JALIAH, I. \& HAFFOR, A. S. Alteraciones morfológicas ultraestructurales durante la exposición a la hiperoxia en relación con la actividad de la glutatión peroxidasa y la producción de radicales libres en las mitocondrias de la corteza cerebral. Int. J. Morphol., 36(4):1310-1315, 2018.

RESUMEN: Se sabe que la exposición a la hiperoxia normobárica (HN) aumenta la producción de especies reactivas de oxígeno (ERO) por parte de las mitocondrias. El estudio se diseñó para examinar los cambios morfológicos de la ultraestructura mitocondrial en la corteza cerebral con la actividad de la glutatión peroxidasa (GPX) y la producción de radicales libres (RL) en el tejido cerebral durante la exposición a la hiperoxia. Los grupos experimentales fueron expuestos a $\mathrm{HN}$ durante 24 y $48 \mathrm{~h}$ continuamente. Tras los períodos de exposición, los animales se sacrificaron y los tejidos corticales se dividieron aleatoriamente en dos partes; la primera parte se procesó para el examen ultraestructural y la segunda se homogeneizó para las determinaciones de GPX y RL. El análisis de varianza (ANOVA) mostró que los efectos principales de los períodos de exposición al $\mathrm{O}_{2}$ fueron significativos $(\mathrm{p}<0,05)$ para GPX y RL. Las comparaciones de medias por pares mostraron que la HN elevó la actividad promedio de GPX (+ SE) significativamente $(\mathrm{p}<0,05)$ desde el valor de control de línea base de 5670,99 $+556,34$ a $13748,42+283,04$ y $15134,19+1529,26 \mathrm{U} / \mathrm{L}$ con una mayor duración del período de exposición a HN de 24 a 48 h, respectivamente. De manera similar, la producción de RL se incrementó significativamente (p $<0,05)$ a $169,73+10,31$ y $185,33+21,87$, por encima del control de referencia de 105,27 +5,25 unidades. El examen de la ultraestructura mostró que la respiración de $\mathrm{O}_{2}$ durante $48 \mathrm{~h}$ dio lugar a mitocondrias gigantes e hinchadas asociadas con la membrana interna diluida y las crestas dañadas. Estas alteraciones patológicas de las mitocondrias se asociaron con daños de mielina, axones y organelos celulares. La hiperoxia normobárica induce el estrés oxidativo mitocondrial (MOS) y el posterior aumento de las ERO provoca una variedad de alteraciones patológicas y morfológicas en los organelos de las células cerebrales corticales.

PALABRAS CLAVE: Corteza cerebral; Alteraciones patológicas y morfológicas; Hiperoxia normobárica; Especies reactivas de oxígeno; Especies reactivas de nitrógeno; Ultraestructura.

\section{REFERENCES}

Balentine, J. D. Pathology of Oxygen Toxicity. $1^{\text {st }}$ ed. New York, Academic Press, 1982.

Bin-Jaliah, I.; Dallak, M. \& Haffor, A. S. Effect of hyperoxia on the ultrastructural pathology of alveolar epithelium in relation to glutathione peroxidase, lactate dehydrogenase activities, and free radical production in rats, Rattus norvigicus. Ultrastruct. Pathol., 33(3):112-22, 2009.
Clemens, S.; Massabuau, J. C.; Meyrand, P. \& Simmers, J. A modulatory role for oxygen in shaping rhythmic motor output patterns of neuronal networks. Respir. Physiol., 128(3):299-315, 2001.

Crapo, J. D.; Barry, B. E.; Foscue, H. A. \& Shelburne, J. Structural and biochemical changes in rat lungs occurring during exposures to lethal and adaptive doses of oxygen. Am. Rev. Respir. Dis., 122(1):123-43, 1980.

Demchenko, I. T.; Atochin, D. N.; Boso, A. E.; Astern, J.; Huang, P. L. \& Piantadosi, C. A. Oxygen seizure latency and peroxynitrite formation in mice lacking neuronal or endothelial nitric oxide synthases. Neurosci. Lett., 344(1):53-6, 2003.

Elayan, I. M.; Axley, M. J.; Prasad, P. V.; Ahlers, S. T. \& Auker, C. R. Effect of hyperbaric oxygen treatment on nitric oxide and oxygen free radicals in rat brain. J. Neurophysiol., 83(4):2022-9, 2000.

Fridovich, I. Oxygen toxicity: a radical explanation.J. Exp. Biol., 201(Pt. 8):12039, 1998.

Gaber, A.; Tamoi, M.; Takeda, T.; Nakano, Y. \& Shigeoka S. NADPH-dependent glutathione peroxidase-like proteins (Gpx-1, Gpx-2) reduce unsaturated fatty acid hydroperoxides in Synechocystis PCC 6803. FEBS Lett., 499(1-2):32-6, 2001.

Haffor, A. S. \& Alttas, O. S. Effects of exposure of rats to periodic versus continuous hyperoxia on antioxidant potentials and free radical production in relation to ultrastructural changes in myocardial cells. Inhal. Toxicol., 22(10):797-804, 2010.

Haffor, A. S. A. Effects of $\mathrm{O}_{2}$ breathing on cardiac mitochondrial GOT and free radical production. J. Med. Sci., 4(2):164-9, 2004.

Hare, J. M.; Givertz, M. M.; Creager, M. A. \& Colucci, W. S. Increased sensitivity to nitric oxide synthase inhibition in patients with brain failure: potentiation of beta-adrenergic inotropic responsiveness. Circulation, 97(2):161-6, 1998.

Jankov, R. P.; Johnstone, L.; Luo, X.; Robinson, B. H. \& Tanswell, A. K. Macrophages as amajor source of oxygen radicals in the hyperoxic newborn rat brain. Free Radic. Biol. Med., 35(2):200-9, 2003.

Lahiri, S.; Mulligan, E.; Andronikou, S.; Shirahata, M. \& Mokashi, A. Carotid body chemosensory function in prolonged normobaric hyperoxia in the cat. $J$. Appl. Physiol. 62(5):1924-31, 1987.

Lipton, A. J.; Johnson, M. A.; Macdonald, T.; Lieberman, M.W.; Gozal, D. \& Gaston, B. S-nitrosothiols signal the ventilatory response to hypoxia. Nature, 413(6852):171-4, 2001.

Mulkey, D. K.; Henderson, R. A. 3rd.; Putnam, R. W. \& Dean, J. B. Hyperbaric oxygen and chemical oxidants stimulate $\mathrm{CO}_{2} / \mathrm{H}+$-sensitive neurons in rat brain stem slices. J. Appl. Physiol. (1985), 95(3):910-21, 2003.

Pellmar, T. C. Use of brain slices in the study of free-radical actions. J. Neurosci. Methods, 59(1):93-8, 1995.

Pellmar, T. C.; Gilman, S. C.; Keyser, D. O.; Lee, K. H.; Lepinski, D. L.; Livengood, D. \& Myers, L. S. Jr. Reactive oxygen species on neural transmission. Ann. N. Y. Acad. Sci., 738:121-9, 1994.

Piantadosi, C. A. \& Tatro, L. G. Regional $\mathrm{H}_{2} \mathrm{O}_{2}$ concentration in rat brain after hyperoxic convulsions. J. Appl. Physiol. (1985), 69(5):1761-6, 1990.

Sawyer, D. B. \& Colucci, W. S. Mitochondrial oxidative stress in heart failure: "oxygen wastage" revisited. Circ. Res., 86(2):119-20, 2000.

Slomka, M.; Zieminska, E.; Salinska, E. \& Lazarewicz, J. W. Neuroprotective effects of nicotinamide and 1-methylnicotinamide in acute excitotoxicity in vitro. Folia Neuropathol., 46(1):69-80, 2008.

Corresponding author:

Prof. Ismaeel Bin-Jaliah

Department of Physiology

College of Medicine

King Khalid University

P.O.Box 641, Abha, 61421

SAUDI ARABIA

\section{E-mail: isbinjaliah@kku.edu.sa}

Recibido : 14-10-2017

Aceptado:16-01-2018 